\title{
ACTIVITY SCREENING AND STRUCTURE MODIFICATION OF ARTOCARPIN AGAINST ACE2 AND MAIN PROTEASE THROUGH IN SILICO METHOD
}

\author{
MUHAMMAD FAUZI ${ }^{*}$, ARIS FADILLAH ${ }^{1}$, FAUZI RAHMAN ${ }^{1}$, JUWITA RAMADHANI ${ }^{1}$, KARINA ERLIANTI ${ }^{1}$, \\ HASNIAH ${ }^{1}$, YULISTIA BUDIANTI SOEMARI', ABDUL MALIK ${ }^{2}$
}

1Faculty of Pharmacy, Islamic University of Kalimantan, Muhammad Arsyad Al Banjari Banjarmasin South Kalimantan, Indonesia 70123, ${ }^{2}$ Faculty of Agriculture, Islamic University of Kalimantan, Muhammad Arsyad Al Banjari Banjarmasin, South Kalimantan, Indonesia 70123 Email: fauzi.ozi1294@gmail.com

Received: 29 Jun 2021, Revised and Accepted: 25 Aug 2021

\begin{abstract}
Objective: SARS-CoV-2 is a type of coronavirus that causes COVID-19 disease. Currently, the right and effective drug for the treatment of COVID-19 has not been found. Artocarpin in the breadfruit plant (Artocarpus altilis), which was tested, has been shown to have antiviral activity. However, artocarpin has a hydroxyl group that can undergo oxidation within a certain time, thereby reducing the stability of the compo und and non-specific antiviral activity.
\end{abstract}

Methods: In this study, the structural modification of artocarpin was carried out to obtain compounds with anticoronavirus activity with good physicochemical properties. This research was conducted in silico, including molecular docking simulation, bioavailability prediction, and preADMET.

Results: The top 20 modified compounds were selected from each target's top 3 compounds, which had better bond energies compared to the positive control. These 3 compounds have the potential to inhibit ACE2 and Mpro receptors and 1 compound are better at inhibiting both.

Conclusion: From the results of the research conducted, we conclude that the 3 best compounds can be potential candidates that can be dev eloped as COVID-19 therapy.

Keywords: Artocarpin, Breadfruit, Drug discovery and drug development, Structure modification, In silico, Covid-19

(C) 2021 The Authors. Published by Innovare Academic Sciences Pvt Ltd. This is an open-access article under the CC BY license (https://creativecommons.org/licenses/by/4.0/) DOI: https://dx.doi.org/10.22159/ijap.2021v13i6.42571. Journal homepage: https://innovareacademics.in/journals/index.php/ijap

\section{INTRODUCTION}

According to the World Health Organization (WHO), more than $80 \%$ of the world's population in developing countries uses medicinal plants derived from plants for their basic medical needs [1]. Indonesia is known as a country that is rich in biodiversity, both in the form of crops consumed as food or plants that have the potential to be developed as drugs or medicinal raw materials. Indonesian people have also recognized and used plants as a solution in maintaining and treating health problems [2].

SARS-CoV-2 is a causative agent for COVID-19, which has caused a pandemic that has affected more than 215 countries and regions worldwide [3]. At the beginning of 2021, there were more than 84 million cases worldwide with more than 1.4 million deaths, where the virus was identified as highly contagious with its pathogenicity, which was a global health threat [4]. The increase in COVID-19 cases and the death rate continues to grow rapidly because there is no effective medicine so that recovery is slow [5].

The problems that arise due to SARS-CoV-2 greatly affect the social and economic life of the international world. This virus transmits without knowing anything, either symptomatic or asymptomatic. During the recovery process, viral RNA expression continued for a long time; even in immunosuppressed patients, the healing process took longer [6]. Regulations of drugs available in some countries around $30-50 \%$ experience a shortage of stock in the treatment of COVID-19. This is influenced by differences in drug regulations in each country because countries have their own regulations [7]. Thus, the search for new drugs to treat this disease needs to be intensified in relation to the problems that occur.

The process of discovering and developing medicines from natural ingredients is continuously being carried out, one of which is the breadfruit plant. This plant is native to Indonesia and Papua New Guinea which is spread throughout Southeast Asia and Africa [8]. Several studies have conducted studies on plants of the Artocarpus genus, namely as an anticancer [9], antitubercular [10], antioxidants [11], antibacterial [12], antiplatelet [13], antifungal [14], antimalarial [15], anti-aging [16], and cytotoxic [17].
Artocarpin compounds are flavonoids found in breadfruit plants. Artocarpin is a flavone compound that is often found in Artocarpus plants which contain prenyl groups at C-3 and C-6 [12]. Artocarpin has a hydroxyl group that can undergo oxidation within a certain time, thereby reducing the stability of the compound. Therefore, efforts are made to increase the activity and improve the stability of artocarpin compounds as candidates for the COVID-19 drug.

In this study, we used two enzymes as molecular targets, namely the ACE2 receptor from the host cell and the Mpro virus. ACE2 receptors are targeted by SARS-CoV-2 in virus transmission to alveolar cells [18]. ACE2 receptor inhibition will be effective for the treatment of COVID-19. Mpro is a non-structural protein that produces mature proteins from the process of cutting two polyprotein replicates to mediate viral replication and transcription. Through this inhibition of Mpro, the virus replication process can be stopped so that it does not change the ACE2 and SARS-CoV-2 conformations blocked into host cells via ACE2 [19] .

\section{MATERIALS AND METHODS}

\section{Ligand preparation and modification}

The compounds used are hydroxychloroquine which is an antimalarial and Nelfinavir which is an HIV-1 protease inhibitor, both drugs are used in COVID-19 therapy. Artocarpin compounds in the form of flavonoids from breadfruit plants as ligands and derivatives of artocarpin compounds. The preparation of artocarpin compounds and their modification is carried out by substitution and addition of certain groups. The modified compound to be used must be made manually using the Chem Office 12 program. After the structural creation is complete, the energy minimizes the compound structure and is saved (pdb). The structure of artocarpin can be seen in fig. 1.

\section{Receptor preparations}

3D crystal receptor structure data used for molecular docking analysis were obtained from PDB on the website http://www.rcsb.org/pdb/. The receptors used to predict activity 
were the ACE2 receptor with PDB 1R4L and Mpro PDB 6LU7. Then the receptors were visualized using the Discovery Studio 2016 Client ${ }^{\circledR}$ program. In this program, the downloaded receptors are prepared by removing water molecules and their natural ligands. The result is a pure receptor which is then stored in the Protein Data Bank (pdb) format.<smiles>CC(C)=CCc1c(O)cc2oc(-c3ccc(O)cc3O)c(CC=C(C)C)c(=O)c2c1O</smiles>

Fig. 1: Artocarpin structure [20]

\section{Docking compounds with receptors}

Docking is done using Autodock4 software. (run-autodock) by dock between ligands and receptors to obtain a population of possible orientations and configurations at the active site. Docking is done by setting the grid center for docking to be $X=40.199, Y=6.024$, and $\mathrm{Z}$ $=28.489$ with grid dimensions $40 \times 40 \times 40$ for $1 \mathrm{R} 4 \mathrm{~L}$. For $6 \mathrm{LU} 7$ the centre of the grid for docking is set $\mathrm{X}=-9.732 \mathrm{Y}=11.403$ and $\mathrm{Z}=68.925$ with grid dimensions of $40 \times 40 \times 40$. After validation of the docking protocol, virtual screening of the compounds was performed by solid molecular docking into the active sites of the two proteins $[21,22]$. During the docking process, the compounds move flexibly and the protein remains rigid. The docking calculation results are viewed in the output in notepad format. Determination of the conformation of the docking test compound is done by selecting the ligand configuration that has the lowest bond energy (the best pose). The position and orientation of the ligand on the macromolecule, as well as the amino acids bound to the ligand, were visualized using the Discovery Studio2016 Client ${ }^{\circledR}$ program to see if the shape matches the mooring site.

\section{Bioavailability prediction and ADMET}

Bioavailability parameters are predicted using Chem Draw 12 . The Chemical structure of the compound is drawn and then its structure is predicted using parameters of molecular weight, partition coefficient, hydrogen donor and acceptor. These results will determine the route of the drug when it is given to the patient. ADMET parameters are calculated using the preADMET $®$ program which is accessed through the website (https://preadmetbmdrc. $\mathrm{kr} / \mathrm{adme} /$ ). The chemical structure of the compounds is drawn or uploaded in Molfile (mol) format. The program automatically calculates the predictive value of the selected parameters, namely: Human colon adenocarcinoma (Caco-2) cell permeability, Human Intestinal Absorption (HIA), Plasma Protein Binding and carcinogenic properties.

\section{RESULTS AND DISCUSSION}

The mortality and morbidity rates from SARS-COV-2 infection are not well known because the case-fatality rate can change over time. The infection rate and the mortality rate continue to increase rapidly and no cure has been found with the right effectiveness for COVID19 , so finding new drugs to treat this disease is very important. Until now, treatment for COVID-19 patients still uses supportive therapy to manage symptoms due to viral infection. Therefore, it is necessary to have potential drug candidates for COVID-19 therapy through natural compounds. Artocarpin is one of the prenylated flavonoid compounds that is most often found in Artocarpus plants. To improve and increase the activity of artocarpin, modifications were made using the addition of a hydroxy group substitution, a prenyl group and a combination of both with alkyl, ester and amide groups [23]. The modification results can be seen in table 1 .

\section{Table 1: Artocarpin derivatives}<smiles>CC(=O)NC(C)(C)CCc1c(-c2ccc(O)cc2O)oc2cc(O)c3c(c2c1=O)OC(C)(C)CC3</smiles>

FIF 1<smiles>CC(=O)NC(C)(C)CCc1c(O)cc2oc(-c3ccc(O)cc3O)c(CCC(C)(C)NC(C)=O)c(=O)c2c1O</smiles>

FIF 3<smiles>COc1cc(O)ccc1-c1oc2cc(O)c(CC=C(C)C)c(O)c2c(=O)c1CCC(C)(C)NC(=O)CC#N</smiles>

FIF 5<smiles>CC(=O)NC(C)(C)CCc1c(-c2ccc(O)cc2O)oc2cc(O)c(CC=C(C)C)c(O)c2c1=O</smiles>

FIF 2<smiles>C=CCC(=O)NC(C)(C)CCc1c(-c2ccc(O)cc2O)oc2cc(O)c3c(c2c1=O)OC(C)(C)CC3</smiles>

FIF 4<smiles>CC(C)(CCc1c(O)cc2oc(-c3ccc(O)cc3O)c(CCC(C)(C)NC(=O)CC#N)c(=O)c2c1O)NC(=O)CC#N</smiles>

FIF 6 
<smiles>CC(=O)Oc1ccc(-c2oc3cc(OC(C)=O)c(CC=C(C)C)c(OC(C)=O)c3c(=O)c2CC=C(C)C)c(OC(C)=O)c1</smiles><smiles>CC(=O)NC(C)(C)CCc1c(-c2ccc(OC(C)=O)cc2OC(C)=[InH])oc2cc(OC(C)=O)c3c(c2c1=O)OC(C)(C)CC3</smiles>

FIF 9

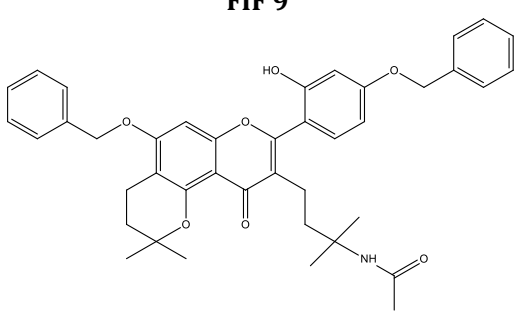<smiles>COc1ccc(-c2oc3cc(OC)c(CC=C(C)C)c(OC)c3c(=O)c2CC=C(C)C)c(OC)c1</smiles>

FIF 13
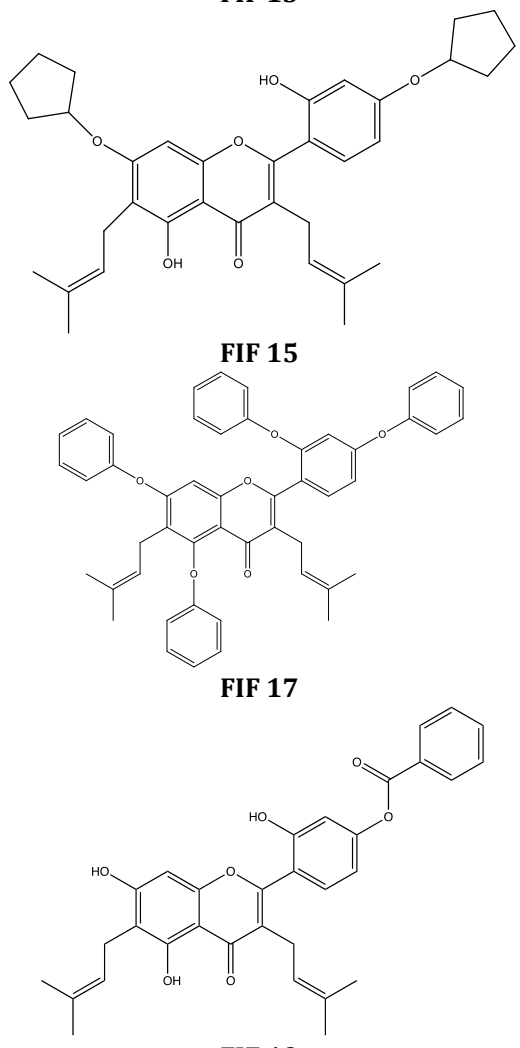<smiles>CC(C)CCc1c(O)cc2oc(-c3ccc(O)cc3O)c(CCC(C)C)c(=O)c2c1O</smiles>

FIF 8

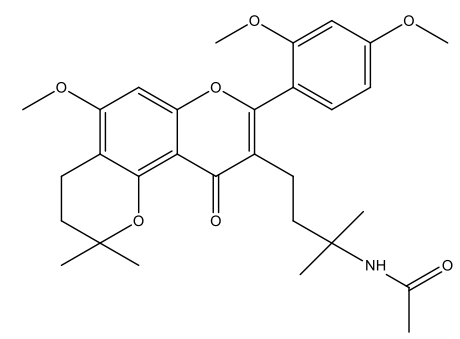

FIF 10

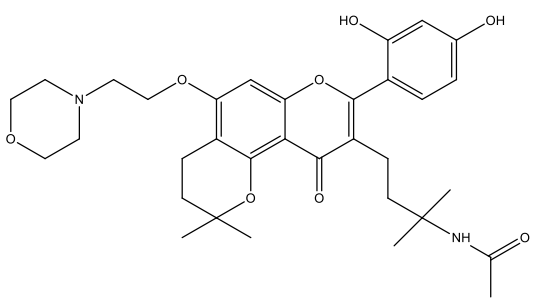

FIF 12

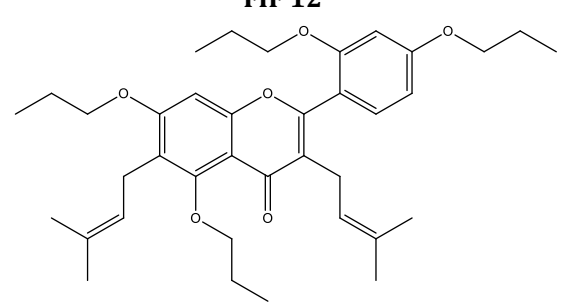

FIF 14

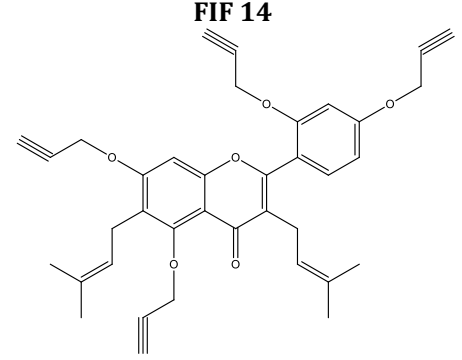

FIF 16

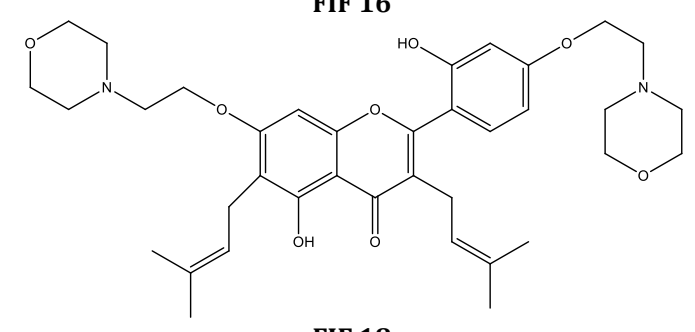

FIF 18

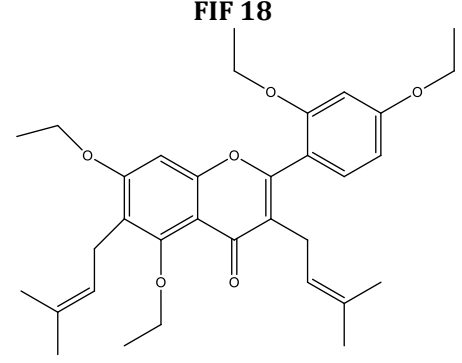

FIF 20 
Simulated docking of the artocarpin molecule and its structural modifications were carried out on the ACE2 and Mpro receptors. The results of molecular docking simulations are shown in table 2 . The parameters observed in the first docking results include the analysis of the bond-free energy $(\Delta G)$ and the inhibition constant (Ki) related to binding affinity. Binding affinity is an important aspect that must be considered in the interaction of ligands and receptors. The results showed that the modified artocarpin compound with the ACE2 receptor was compared with the positive control for hydroxychloroquine, the 3 best-modified rankings were obtained, namely FIF $11=-12.08 \mathrm{kcal} / \mathrm{mol}$ and $\mathrm{Ki}=1.40 \mathrm{nM}$, FIF $12=-12.42$ $\mathrm{kcal} / \mathrm{mol}$ and $\mathrm{Ki}=0.789 \mathrm{nM}$., and FIF $17=-13.00 \mathrm{kcal} / \mathrm{mol}$ and $\mathrm{Ki}=$ $0.294 \mathrm{nM}$, these three compounds have the lowest energy and strongest inhibition constant than the positive control hydroxychloroquine-7.92 $\mathrm{kcal} / \mathrm{mol} 628.17 \mathrm{nM}$. The results for the molecular docking simulation of Mpro also obtained the 3 best ranks, namely FIF $1=-11.48 \mathrm{kcal} / \mathrm{mol}$ and $\mathrm{Ki}=3.83 \mathrm{nM}$, FIF $7=-12.15 \mathrm{kcal} / \mathrm{mol}$ and $\mathrm{Ki}=1.25 \mathrm{nM}$, and FIF $17=-12.35 \mathrm{kcal} / \mathrm{mol}$ and $\mathrm{Ki}=0.881 \mathrm{nM}$. The results of docking the positive control of nelfinavir were higher, namely-10.52 $\mathrm{kcal} / \mathrm{mol}$ and $\mathrm{Ki}=19.49 \mathrm{nM}$. For the artocarpin compound before modification, molecular docking was also carried out to the two receptors, the results were $-9.30 \mathrm{kcal} / \mathrm{mol}$ and $\mathrm{Ki}$ of $151.88 \mathrm{nM}$ with ACE2 receptors and-9.88 kcal/mol and inhibition constant $56.89 \mathrm{nM}$ with Mpro. Experimentally $\Delta \mathrm{G}$ is directly related to $\mathrm{Ki}$, this is following the equation: $\Delta \mathrm{G}=$-RT $\mathrm{Ln} \mathrm{Ki}$. Thus, the value of $\Delta \mathrm{G}$ is can predict the ability of a compound to inhibit protein [24].

Table 2: Binding affinity $(\Delta G)$ and inhibition constant (Ki)

\begin{tabular}{|c|c|c|c|c|c|}
\hline \multirow[t]{2}{*}{ No } & \multirow[t]{2}{*}{ Compounds } & \multicolumn{2}{|l|}{ ACE2 Receptor } & \multicolumn{2}{|l|}{ Mpro } \\
\hline & & $\Delta \mathrm{G}(\mathrm{kcal} / \mathrm{mol})$ & Ki (nM) & $\Delta \mathrm{G}(\mathrm{kcal} / \mathrm{mol})$ & Ki (nM) \\
\hline 1. & Artocarpin & -9.30 & 151.88 & -9.88 & 56.89 \\
\hline 2. & FIF 1 & -9.89 & 56.59 & -11.48 & 3.83 \\
\hline 3. & FIF 2 & -9.67 & 81.81 & -10.04 & 43.44 \\
\hline 4. & FIF 3 & -10.04 & 43.56 & -10.16 & 35.72 \\
\hline 5. & FIF 4 & -10.12 & 38.04 & -10.68 & 14.82 \\
\hline 6. & FIF 5 & -9.54 & 101.43 & -10.16 & 35.96 \\
\hline 7. & FIF 6 & -8.90 & 298.14 & -9.82 & 63.19 \\
\hline 8. & FIF 7 & -9.22 & 173.35 & -12.15 & 1.25 \\
\hline 9. & FIF 8 & -9.18 & 187.87 & -9.78 & 67.93 \\
\hline 10. & FIF 9 & -10.99 & 8.76 & -11.47 & 3.93 \\
\hline 11. & FIF 10 & -10.05 & 42.95 & -10.79 & 12.23 \\
\hline 12. & FIF 11 & -12.08 & 1.40 & -11.07 & 7.70 \\
\hline 13. & FIF 12 & -12.42 & 0.789 & -11.47 & 3.89 \\
\hline 14. & FIF 13 & -8.07 & 1.22 & -9.80 & 65.38 \\
\hline 15. & FIF 14 & -8.72 & 409.03 & -8.87 & 316.11 \\
\hline 16. & FIF 15 & -10.95 & 9.40 & -11.17 & 6.50 \\
\hline 17. & FIF 16 & -8.71 & 410.20 & -8.63 & 471.54 \\
\hline 18. & FIF 17 & -13.00 & 0.294 & -12.35 & 0.881 \\
\hline 19. & FIF 18 & -11.53 & 3.52 & -10.32 & 27.38 \\
\hline 20. & FIF 19 & -11.98 & 1.64 & -10.32 & 27.47 \\
\hline 21. & FIF 20 & -9.45 & 117.56 & -9.47 & 114.49 \\
\hline
\end{tabular}

In addition, in terms of their bonds with amino acids, the three best compounds have interactions at the active site of the ACE 2 receptor with various amino acids formed form hydrogen bonds. The modified FIF 11 compound binds the amino acid ARG273, the FIF 12 compound binds the amino acids HIS374, TYR515, ARG514, and FIF 17 binds the amino acids GLU402, GLU406, ALA348, ARG273, HIS345. For positive control, the drug hydroxychloroquine binds the amino acids HIS374 and GLU402. The presence of a hydrogen bond between the target amino acid protein glutamine and histidine is responsible for the catalytic activity of the domain at the ACE2 receptor. Then for compounds that interact on the active side of Mpro also bind amino acids, namely FIF 1 binds to amino acids GLY143, FIF 7 binds to amino acids MET165, ARG188, HIS164, CYS145, and FIF 17 binds amino acids ASP187, GLU166, ASN142, LEU141, GLN189, whereas for positive control nelfinavir binds to the amino acids THR190, GLU166, GLN189. The similarity of amino acids between the drug and the positive control became an inhibitor in the viral replication process because it had the same properties as the positive control as an antiviral. The results of the compound interactions are shown in fig. 2.

Table 3: Lipinski's rule of five prediction

\begin{tabular}{|c|c|c|c|c|c|}
\hline No & Compounds & molecular weight & $\log P$ & H Donor & H Acceptor \\
\hline 1. & Artocarpin & 422.17 & 4.57 & 4 & 6 \\
\hline 2. & FIF 1 & 481.21 & 2.78 & 4 & 7 \\
\hline 3. & FIF 2 & 481.21 & 3.18 & 5 & 7 \\
\hline 4. & FIF 3 & 540.25 & 1.8 & 6 & 8 \\
\hline 5. & FIF 4 & 506.21 & 2.98 & 4 & 8 \\
\hline 6. & FIF 5 & 506.21 & 3.38 & 5 & 8 \\
\hline 7. & FIF 6 & 590.24 & 2.2 & 6 & 10 \\
\hline 8. & FIF 7 & 590.22 & 4.47 & 0 & 6 \\
\hline 9. & FIF 8 & 426.50 & 5.52 & 4 & 6 \\
\hline 10. & FIF 9 & 607.24 & 2.71 & 1 & 7 \\
\hline 11. & FIF 10 & 523.26 & 3.57 & 1 & 6 \\
\hline 12. & FIF 11 & 661.30 & 6.77 & 2 & 5 \\
\hline 13. & FIF 12 & 594.29 & 2.65 & 3 & 9 \\
\hline 14. & FIF 13 & 478.24 & 5.62 & 1 & 6 \\
\hline 15. & FIF 14 & 590.36 & 8.92 & 0 & 6 \\
\hline 16. & FIF 15 & 558.30 & 7.36 & 2 & 6 \\
\hline 17. & FIF 16 & 574.24 & 6.48 & 0 & 6 \\
\hline 18. & FIF 17 & 726.30 & 12.27 & 0 & 2 \\
\hline 19. & FIF 18 & 648.34 & 4.26 & 2 & 10 \\
\hline 20. & FIF 19 & 526.20 & 6.44 & 3 & 6 \\
\hline 21. & FIF 20 & 534.30 & 6.97 & 0 & 6 \\
\hline
\end{tabular}



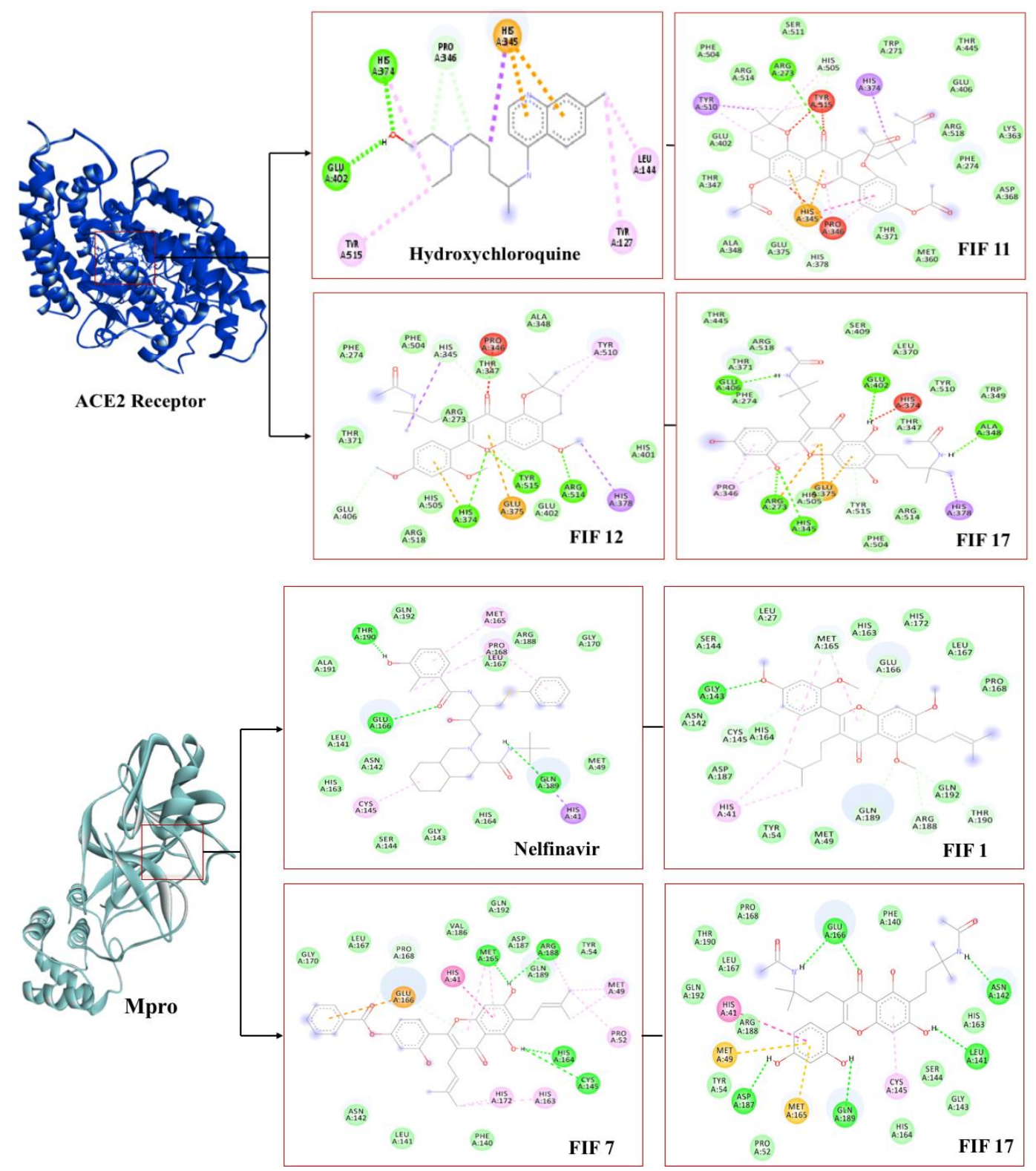

Fig. 2: Best visualization of molecular docking result of drugs and ligand modification with ACE2 and Mpro

Lipinski's Rule of Five is a rule for evaluating the physicochemical properties of compounds to be administered orally [25]. This rule describes the physicochemical properties of the pharmacokinetic phase in the human body. Therefore, in designing drugs to be administered orally, it is expected that they meet Lipinski's Rule of Five. Based on this rule, the results of some compounds do not meet Lipinski's Rule of Five. This is because the compound has a large structure so that when modified has an impact on increasing molecular weight and $\log \mathrm{P}$; the results are shown in table 3 . Therefore the 3 best compounds based on the results of molecular docking are not recommended to be given orally because they do not have good bioavailability.

Absorption, distribution, and toxicity are very important in the pharmaceutical field to assess a drug candidate in the body [26] Absorption parameters consist of HIA (Human Intestinal Absorption) and permeability to Caco-2 cells and distribution parameters, namely PPB (Protein Plasma Binding) and BBB (Blood Brain Barrier) and toxicity parameters consisting of carcinogenic and mutagenic properties (table 4).

Human Intestinal Absorption (HIA) indicates the absorption of drugs by the human intestine. The HIA value of $0-20 \%$ indicates that the compound is poorly absorbed, the HIA value of $20-70 \%$ indicates that the compound is sufficiently absorbed, and the HIA value of 70 $100 \%$ indicates that the compound is well absorbed [27]. The values of HIA FIF 1, FIF 7, FIF 11, FIF12, and FIF17 were 88.03\%, 98.47\%, $98.05 \%, 97.48 \%$ and $98.46 \%$. Artocarpin compounds have a smaller HIA value, namely $89.06 \%$ compared to modified FIF compounds, which shows that artocarpin modified compounds can be relatively well absorbed by the intestine.

The Caco-2 cell model has been recommended as a good in vitro model for the prediction of oral drug absorption. A Caco-2 value of less than 4 indicates low drug permeability, a value of 4-70 indicates moderate permeability, and a Caco 2 value of more than 70 indicates high permeability $[28,29]$. The Caco-2 FIF 1 , FIF 7, FIF 11, FIF12, and FIF 17 scores were 19.76, 30.08, 41.15, 44.08 and 48.83, respectively, indicating that these five drug candidates could penetrate the medium cell membrane.

The degree of drug binding to plasma proteins affects the pharmacokinetic profile of the drug and the pharmacodynamic profile of the drug. PPB values of more than $90 \%$ indicate strong chemical bonds, while values less than $90 \%$ indicate weak chemical bonds [23]. The values of PPB FIF 1, FIF 7, FIF 11, FIF12, and FIF17 
were $88.03 \%, 91.15 \%, 91.27 \%, 10.42 \%$ and $4.03 \%$, respectively. These results indicate that only a few molecules of the four drug candidates can reach the receptor and one compound is absorbed into the receptor.

Table 4: Pharmacokinetic and toxicity prediction

\begin{tabular}{|c|c|c|c|c|c|c|c|}
\hline \multirow[t]{2}{*}{ No } & \multirow[t]{2}{*}{ Compounds } & \multicolumn{2}{|c|}{ Absorption } & \multicolumn{2}{|c|}{ Distribution } & \multicolumn{2}{|l|}{ Toxicity } \\
\hline & & HIA (\%) & Caco2 & PPB & BBB & Mutagenic & Carsinogenic \\
\hline 1. & Artocarpin & 89.06 & 18.01 & 100 & 3.02 & + & + \\
\hline 2. & FIF 1 & 88.03 & 19.76 & 88.03 & 0.26 & - & - \\
\hline 3. & FIF 2 & 81.61 & 19.60 & 91.64 & 0.47 & - & - \\
\hline 4. & FIF 3 & 69.27 & 19.89 & 84.18 & 0.11 & - & - \\
\hline 5. & FIF 4 & 85.40 & 18.16 & 88.75 & 0.14 & - & - \\
\hline 6. & FIF 5 & 80.46 & 19.26 & 88.47 & 0.27 & - & - \\
\hline 7. & FIF 6 & 49.33 & 19.58 & 84.59 & 0.05 & - & + \\
\hline 8. & FIF 7 & 98.37 & 30.08 & 91.15 & 0.05 & - & + \\
\hline 9. & FIF 8 & 87.67 & 18.08 & 100 & 3.72 & + & + \\
\hline 10. & FIF 9 & 97.34 & 36.04 & 86.68 & 0.12 & - & - \\
\hline 11. & FIF 10 & 96.81 & 56.02 & 88.98 & 0.03 & - & - \\
\hline 12. & FIF 11 & 98.05 & 41.15 & 91.27 & 0.46 & - & - \\
\hline 13. & FIF 12 & 97.48 & 44.08 & 10.42 & 0.17 & - & + \\
\hline 14. & FIF 13 & 97.43 & 57.22 & 91.72 & 0.24 & - & + \\
\hline 15. & FIF 14 & 97.98 & 54.11 & 95.90 & 12.19 & - & - \\
\hline 16. & FIF 15 & 98.24 & 40.94 & 99.20 & 16.23 & - & + \\
\hline 17. & FIF 16 & 97.97 & 36.23 & 100 & 10.26 & - & - \\
\hline 18. & FIF 17 & 98.46 & 48.83 & 100 & 4.03 & - & + \\
\hline 19. & FIF 18 & 97.83 & 38.59 & 11.02 & 1.54 & + & + \\
\hline 20. & FIF 19 & 94.38 & 22.89 & 100 & 4.03 & + & - \\
\hline 21. & FIF 20 & 97.57 & 41.26 & 91.71 & 1.22 & - & - \\
\hline
\end{tabular}

Blood-Brain Barrier (BBB) penetration indicates the concentration of the drug in the brain and blood to avoid CNS side effects. A BBB value of more than 2.0 indicates that the compound can be highly absorbed in the CNS and a BBB value between 2.0-0.1 indicates a moderate absorption rate in the CNS. A BBB value less than 0.1 indicates a low absorption rate in the CNS[30]. The values of $\mathrm{BBB}$ nelfinavir, FIF 1, FIF 7, FIF 11, FIF12, and FIF17 were 0.26, 0.05, $0.46,0.27$ and 4.04, respectively. Based on these data, the FIF 17 compound is an ideal compound to target the ACE2 and Mpro receptors which have low absorption in the CNS.

The toxicity of artocarpin and its modified compounds was tested using the Ames test to determine the mutagenicity and carcinogenicity properties using the in vivo method on mice predicted by PreADMET. The Ames test is a biological test that uses bacteria to assess the mutagenic potential of a chemical compound. Based on the Ames test, artocarpin is mutagenic, which indicates that it can cause permanent changes in genes. Artocarpin, FIF 7 and FIF 17 are carcinogenic which can potentially cause cancer. The relationship between mutagenicity and carcinogenicity is that mutations occur only in organs that have the potential to become cancerous.

\section{CONCLUSION}

This research was conducted to find novel inhibitor molecules against the two enzymes ACE2 and Mpro. The developed molecule comes from the Artocarpus plant, namely artocarpin, where the structure is fixed to obtain a potential candidate compound. Modifications were made as many as 20 compounds using functional group substitution, then all modifications were predicted in silico. The results of 20 modified compounds had a better activity with each of the 3 compounds having the best potential in inhibiting the two enzymes. Modified compounds FIF 11, FIF 12 and FIF 17 are able to act as inhibitors of ACE2 and FIF 1, FIF 7 and FIF 17 enzymes and are also can act as Mpro inhibitors. FIF 17 compounds can bind more efficiently and provide inhibitor activity to the two enzymes, namely ACE2 and Mpro. Thus, we conclude that these modified results can be used as potential antivirus candidates. This new molecule could be used for further innovation and development of antiviral compounds for COVID-19 therapy.

\section{ABBREVIATION}

SARS-CoV-2: Severe Acute Respiratory Syndrome Coronavirus 2; COVID-19: Corana Virus Diseases 2019; ACE2: Angiotensin
Converting Enzyme-2; HIV-1: Human Immunodeficiency Virus Type 1; PDB: Protein Data Bank; ADMET: Absorption, Distribution, Metabolism, Excretion and Toxicity; Ki: Inhibition Constant; HIA: Human Intestinal Absorption; PPB: Protein Plasma Binding; BBB: Blood-Brain Barrier; CNS: Central Nervous System

\section{ACKNOWLEDGMENT}

This research was funded by the Islamic University of Kalimantan Muhammad Arsyad Al Banjari Banjarmasin. The first author would like to thank the Islamic University of Kalimantan for APBU Uniska 2020/2021 research grant.

\section{FUNDING}

Nil

\section{AUTHORS CONTRIBUTIONS}

All the authors have contributed equally.

\section{CONFLICT OF INTERESTS}

Declared none

\section{REFERENCES}

1. Canter PH, Thomas H, Ernst E. Bringing medicinal plants into cultivation: opportunities and challenges for biotechnology. Trends Biotechnol. 2005;23(4):180-5. doi: 10.1016/ j.tibtech.2005.02.002, PMID 15780709.

2. Pramono E. The commercial use of traditional knowledge and medicinal plants in Indonesia. Submitt multi-stakeholder dialogue trade, Intellect prop Biol Resour. Asia; 2002.

3. Chhikara BS, Rathi B, Singh J, FNU P. Coronavirus SARS-CoV-2 disease COVID-19: infection, prevention and clinical advances of the prospective chemical drug therapeutics: a review on coronavirus disease covid-19, epidemiology, prevention, and anticipated therapeutic advances. Chem Biol 2020;7:63-72.

4. World Health Organization. Coranavirus Disease 2019 (COVID19) report situation [Internet]; 2021. Available from: https://www.who.int/emergencies/diseases/novel-coronavirus2019/situation-reports/ [Last accessed on 19 Feb 19 2021]

5. Muchtaridi M, Fauzi NKK Ikram, Amirah Mohd Gazzali HAW. Natural flavonoids as the potential for anti-SARS-CoV-2. Mdpi [Internet]. Vol. 2. p. 20. Available from: https://www.mdpi;2020.Com/1420-3049/25/17/3980 [Last accessed on 07 Sep 2021]. 
6. Tunas IK, Ayu D, Sri A, Widyadharma I, Putu LUH, Sundari R. Review article the efficacy of Covid-19 vaccine and the challenge in implementing mass vaccination in Indonesia. 2021;13:4-6.

7. Vignesh M, Ganesh GNK. Pharmacy professions in India during covid-19 pandemic: present status, future challenges and a way forward. Int J Appl Pharm. 2021;13:32-5.

8. Appiah F, Oduro I, Ellis WO. Proximate and mineral composition of Artocarpus altilis pulp flour as affected by fermentation. Pak J Nutr. 2011;10(7):653-7. doi: 10.3923/pjn.2011.653.657.

9. Nonpanya N, Sanookpan K, Sriratanasak N, Vinayanuwattikun C, Wichadakul D, Sritularak B, Chanvorachote P. Artocarpin targets focal adhesion kinase-dependent epithelial to mesenchymal transition and suppresses migratory-associated integrins in lung cancer cells. Pharmaceutics. 2021;13(4):1-22. doi: 10.3390/pharmaceutics13040554, PMID 33920031.

10. Boonphong S, Baramee A, Kittakoop P. Antitubercular and antiplasmodial prenylated flavones from the roots of Artocarpus altilis. Chiang Mai J Sci. 2007;34:339-44.

11. Lee CW, Chi MC, Chang TM, Liu JF. Artocarpin induces cell apoptosis in human osteosarcoma cells through endoplasmic reticulum stress and reactive oxygen species. J Cell Physiol. 2019;234(8):13157-68. doi: 10.1002/jcp.27986, PMID 30549031.

12. Sadiah K, Yuwono SD, Qudus HI, Yandri T, Suhartati T. Isolation, Characterization, Modification of artocarpin Compound from Pudau Plant (Artocarpus kemando Miq.) and Bioactivity antibacterial Assay of artocarpin Compound and Their Modification Result. IOP Conf Ser.: Earth Environ Sci. 2020;537:12047. doi: 10.1088/1755-1315/537/1/012047.

13. Weng JR, Chan SC, Lu YH, Lin HC, Ko HH, Lin CN. Antiplatelet prenylflavonoids from Artocarpus communis. Phytochemistry. 2006;67(8):824-9. doi: 10.1016/j.phytochem.2006.01.030, PMID 16516939.

14. Jayasinghe L, Balasooriya BA, Padmini WC, Hara N, Fujimoto Y. Geranyl chalcone derivatives with antifungal and radical scavenging properties from the leaves of Artocarpus nobilis. Phytochemistry. 2004;65(9):1287-90. doi: 10.1016/ j.phytochem.2004.03.033, PMID 15184014.

15. Suhartati T, Epriyanti E, Borisha I, Yandri SJF, Suwandi JF, Yuwono SD, Qudus HI, Hadi S. In vivo antimalarial test of artocarpin and in vitro antimalarial test of artonin $\mathrm{M}$ isolated from artocarpus. Rev Chim. 2020;71(5):400-8. doi: 10.37358/RC.20.5.8150.

16. Shim JH. Anti-aging effect of artocarpin in UVA-irradiated normal human epidermal keratinocytes. Korean J Pharmacogn. 2020;51:49-54.

17. Jeyamogan S, Khan NA, Siddiqui R. Antitumour activities of selected pure compounds identified from the serum of crocodylus porosus, malayopython reticulatus, varanus salvator and cuora kamaroma amboinensis. Asian Pac J Cancer Prev. 2021;22(S1):97-106. doi: 10.31557/APJCP.2021.22.S1.97, PMID 33576218.

18. Bahbah EI, Negida A, Nabet MS. Purposing saikosaponins for the treatment of COVID-19. Med Hypotheses. 2020;140:109782. doi: 10.1016/j.mehy.2020.109782, PMID 32353743.

19. Zamai L. The yin and yang of ACE/ACE2 pathways: the rationale for the use of renin-angiotensin. Vol. 5. mdpi; 2020. p. 1-35.

20. Morrison IJ, Zhang J, Lin J, Murray JE, Porter R, Langat MK, Sadgrove NJ, Barker J, Zhang G, Delgoda R. Potential chemopreventive, anticancer and anti-inflammatory properties of a refined artocarpin-rich wood extract of Artocarpus heterophyllus Lam. Sci Rep. 2021;11(1):6854. doi: 10.1038/s41598-021-86040-5, PMID 33767225.

21. Ibrahim FM, Holik HA, Achmad A. In silico studies of amentoflavone and Its Derivatives Against Sars-Cov-2. Rasayan J Chem. 2021;14:1469-81. doi: 10.31788/RJC.2021.1436172

22. Joshi T, Joshi T, Sharma P, Mathpal S, Pundir H, Bhatt V, Chandra S. In silico screening of natural compounds against COVID-19 by targeting Mpro and ACE2 using molecular docking. Eur Rev Med Pharmacol Sci. 2020;24(8):4529-36. doi: 10.26355/eurrev_202004_21036, PMID 32373991.

23. Fauzi M, Muchtaridi M. Synthesis and anti-breast cancer activities of alpha mangostin derivatives: a review. Cancer. 2020;13:2544-51.

24. Muttaqin FZ. Molecular docking and dynamic molecular studies of stilbene derivative compounds as Sirtuin-3 (Sirt3) histone deacetylase inhibitor on melanoma skin cancer and their toxicities prediction. J Pharm. 2019;2(2):112-21. doi: 10.36465/jop.v2i2.489.

25. Lipinski CA. Lead- and drug-like compounds: the rule-of-five revolution. Drug Discovery Today Technol. 2004;1(4):337-41. doi: 10.1016/j.ddtec.2004.11.007, PMID 24981612.

26. F Pratama K, Fauzi M, Hasanah AN. Activity screening and structure modification of trigonelline as new anticancer drug for non-small cell lung cancer through in silico. Indonesian J Pharm Sci Technol. 2020;7(3):90. doi: 10.24198/ijpst.v7i3.26765.

27. Cheng F, Li W, Liu G, Tang Y. In silico ADMET prediction: recent advances, current challenges and future trends. Curr Top Med Chem. 2013;13(11):1273-89. doi: 10.2174/ 15680266113139990033 , PMID 23675935.

28. Fauzi M, Saptarini NM, Mustarichie R. In silico screening of compounds contained in wera (Malvaviscus arboreus cav.) leaves as anti-alopecia with androgen receptors. J Glob Pharma Technol. 2019;11:309-17.

29. Yazdanian M, Glynn SL, Wright JL, Hawi A. Correlating partitioning and Caco-2 cell permeability of structurally diverse small molecular weight compounds. Pharm Res. 1998;15(9):1490-4. doi: 10.1023/a:1011930411574, PMID 9755906.

30. Cheng C, Jie YMa XL, Chen C, Yang J. Predictive model of bloodbrain barrier penetration of organic compounds1. Acta Pharmacol Sin. 2005;26(4):500-12. doi: 10.1111/j.17457254.2005.00068.x, PMID 15780201. 